\title{
GMR
}

\section{Molecular diversity of Pakistani mango (Mangifera indica $L$.) varieties based on microsatellite markers}

T. Nazish' ${ }^{1}$ G. Shabbir ${ }^{1}$, A. Ali ${ }^{2}$, S. Sami-ul-Allah ${ }^{3}$, M. Naeem ${ }^{4}$, M. Javed ${ }^{5}$, S. Batool ${ }^{1}$, H. Arshad ${ }^{1}$, S.B. Hussain ${ }^{1}$, K. Aslam ${ }^{1}$, R. Seher ${ }^{1}$, M. Tahir ${ }^{1}$ and M. Baber ${ }^{1}$

${ }^{1}$ Institute of Molecular Biology and Biotechnology, Bahauddin Zakariya University, Multan, Pakistan ${ }^{2}$ Institute of Pure and Applied Biology, Zoology Division, Bahauddin Zakariya University, Multan, Pakistan ${ }^{3}$ College of Agriculture, Sub-Campus Layyah, Bahauddin Zakariya University, Multan, Pakistan ${ }^{4}$ Department of Plant Breeding and Genetics, University College of Agriculture, Islamia University,

Bahawalpur, Pakistan

${ }^{5}$ Department of Plant Breeding and Genetics, Bahauddin Zakariya University, Multan, Pakistan

Corresponding author: M. Baber

E-mail: muhammadbabar@bzu.edu.pk

Genet. Mol. Res. 16 (2): gmr16029560

Received November 30, 2016

Accepted February 8, 2017

Published April 5, 2017

DOI http://dx.doi.org/10.4238/gmr16029560

Copyright (C) 2017 The Authors. This is an open-access article distributed under the terms of the Creative Commons Attribution ShareAlike (CC BY-SA) 4.0 License.

ABSTRACT. Understanding the genetic diversity of different Pakistani mango varieties is important for germplasm management and varietal characterization. Microsatellites are efficient and highly polymorphic markers for comparative genome mapping, and were used in the present study to determine the genetic relatedness and variability among 15 indigenous mango cultivars (Mangifera indica L.). Overall, 181 bands

Genetics and Molecular Research 16 (2): gmr16029560 
were produced using 12 simple sequence repeat (SSR) primers. Out of the 12 primers used, 10 were polymorphic and two were monomorphic. Genetic relatedness among cultivars was assessed by constructing a dendrogram using the unweighted pair group method of arithmetic means. The accessions exhibited coefficients of similarity ranging from 75 to $100 \%$, indicating the frequent use of only a few parent cultivars and the presence of inbreeding. The primers used in the present study were found to be valuable for identifying genetic relationships among mango cultivars.

Key words: Microsatellites; Mango (Mangifera indica L.); Genetic relatedness; Inbreeding

\section{INTRODUCTION}

Mango is the second largest fruit crop of Pakistan after citrus, with a cultivated area of 167.5 thousand hectares, and production of 1,732 thousand tones. It is grown in 100 countries, with an estimated annual production of 25 million tones. Pakistan produces $8.5 \%$ of the world's mangoes, mainly exported to the Middle East, Iran, Germany, Japan, China, and Hong Kong, highlighting the valuable contribution of this fruit crop to the country's economy (Rashad et al., 2012). Sindh and Punjab are major mango-producing provinces. In Punjab, leading districts in mango production are Muzzaffargarh, Multan, Bahawlpur, and Rahim Yar Khan, which grow major varieties, such as Langra, Zafran, Sindhri, Dusehri, Desi, Kala, and Sufaid-Chaunsa. According to the Food and Agriculture Organization, the top mango-producing countries are China, India, Thailand, Indonesia, and the United States, with Pakistan being ranked number six globally (Food and Agriculture Organization Report, 2013).

Several factors, including selection, mutation, genetic drift, and recombination, provide sources of genetic diversity. Varieties contain high levels of genetic variation, which represent valuable genetic resources because these can be used to broaden the gene pool of advanced genotypes (Kobayashi et al., 2006). Molecular markers are valuable tools for the assessment of genetic variation (Varshney et al., 2005), and therefore assist in selection. Among the available molecular markers, PCR-based markers are the most suitable for revealing genetic diversity, and include randomly amplified polymorphic DNA (RAPD), simple sequence repeat (SSR), inter simple sequence repeat (ISSR), and amplified fragment length polymorphism (AFLP) markers. Among these, SSRs are receiving attention due to their multiallelic nature, reproducibility, hypervariability, codominant inheritance, comprehensive genome coverage, relative abundance, tractability to automation, chromosome-fixed location, and suitability for high-throughput genotyping (Parida et al., 2009). These qualities led us to use SSRs to explore variation among mango cultivars.

SSR markers have been effectively utilized for estimating genetic variability in mango (Honsho et al., 2005; Dos Santos Ribeiro et al., 2012; Shamili et al., 2012; Ravishankar et al., 2015). The present study was conducted to investigate the genetic variability and relatedness among 15 different mango cultivars from Pakistan using SSR markers. These findings will be helpful for mango breeders for future breeding programs and management.

Genetics and Molecular Research 16 (2): gmr16029560 


\section{MATERIAL AND METHODS}

The germplasm of 15 commercially grown mango varieties (Table 1) were collected from Mango Research Station, Shujabad, and Mango Research Centre, Multan. Three to five young leaves were picked as samples, placed in plastic zip lock packs, and kept in an ice box for protection during transportation. Upon reaching the laboratory, the germplasm was moved to $-80^{\circ} \mathrm{C}$ freezers until use. Wet laboratory experiments were conducted at the Genome Mapping Laboratory of the Institute of Molecular Biology and Biotechnology, Bahauddin Zakariya University, Multan, Pakistan.

\section{Table 1. Selected cultivars of mango used for diversity analysis.}

\begin{tabular}{l|l|l}
\hline Serial No. & Cultivar & Region of sampling \\
\hline 1 & Langra & Multan \\
\hline 2 & Sufaid-Chaunsa & Multan \\
\hline 3 & Kala-Chaunsa & Multan \\
\hline 4 & Zafran & Shujabad \\
\hline 5 & Sindhri & Shujabad \\
\hline 6 & Dusehri & Shujabad \\
\hline 7 & Neelam & Shujabad \\
\hline 9 & Samar Bhisht-Chaunsa & Shujabad \\
\hline 10 & Fajri & Shujabad \\
\hline 11 & Desi & Multan \\
\hline 12 & Taimuria & Shujabad \\
\hline 13 & Burma Surkha & Shujabad \\
\hline 15 & Lahotia & Shujabad \\
\hline & Anwar Ratol & Shujabad \\
\hline
\end{tabular}

\section{DNA extraction and SSR marker analysis}

Genomic DNA from the leaf samples was extracted according to the cetyl trimethyl ammonium bromide (CTAB) protocol described by Doyle and Doyle (1990). The quality and quantity of DNA was measured using a $0.8 \%$ agarose gel. After electrophoresis, the DNA was visualized under ultraviolet (UV) light (Trans Illuminator). DNA was quantified using a spectrophotometer and $5.0 \mathrm{ng} / \mu \mathrm{L}$ was the final working concentration used for $25-\mu \mathrm{L}$ polymerase chain reactions (PCRs). Twelve SSR markers (Table 2) were used to analyze 15 mango varieties. These primers were used based on previously published data (Dillon et al., 2014). Selected SSR markers were based on tri-, tetra-, penta-, and hexa-repeat motifs of these markers, which were deemed helpful for the assessment of genetic diversity.

\section{Polymerase chain reaction (PCR)}

PCR for SSR analysis was performed using gene-specific primers (Table 2). The total reaction volume for PCR was $25 \mu \mathrm{L}$, containing $3 \mu \mathrm{L}$ template DNA (15 ng), $2.5 \mu \mathrm{L} \mathrm{MgCl}_{2}$, $2.5 \mu \mathrm{L}$ 10X PCR buffer, $2.5 \mu \mathrm{L}$ dNTPs, $3 \mu \mathrm{L}$ each forward and reverse primer, $1 \mathrm{U}$ Taq polymerase, and $9.9 \mu \mathrm{L}$ PCR water. PCR was performed using a Gene Amp ${ }^{\circledR}$ system (Applied Biosystems). The PCR profile included initial denaturation for $5 \mathrm{~min}$ at $95^{\circ} \mathrm{C}$, followed by 35 cycles of denaturation at $94^{\circ} \mathrm{C}$ for $30 \mathrm{~s}$, annealing at $55^{\circ} \mathrm{C}$ for $30 \mathrm{~s}$, extension at $72^{\circ} \mathrm{C}$ for 1 min, and final extension at $72^{\circ} \mathrm{C}$ for $10 \mathrm{~min}$. PCR products were separated on $1.5 \%$ agarose gel 
and bands were visualized under UV light. One-kilobase plus DNA ladder was loaded onto the gels to estimate the size of PCR products from mango varieties.

Table 2. SSR primers used for diversity analysis in mango.

\begin{tabular}{|c|c|c|c|c|c|}
\hline Serial No. & Primer name & Accession No. & Primer sequence $\left(5^{\prime}-3^{\prime}\right)$ & Annealing temperature $\left({ }^{\circ} \mathrm{C}\right)$ & Size range (bp) \\
\hline 1 & QGMi001 & JZ532296 & $\begin{array}{l}\text { GAAAGGCTTGCAGAGACAGG } \\
\text { GTTTCTTCTGTTCGGTGATGGAGGAGT }\end{array}$ & 55 & $171-227$ \\
\hline 2 & QGMi002 & JZ532297 & $\begin{array}{l}\text { GCTCAACCTCTTTCCTGCTC } \\
\text { GTTTCTTCAATCCCCAGAAGAAAACCA }\end{array}$ & 55 & $241-269$ \\
\hline 3 & QGMi003 & JZ532319 & $\begin{array}{l}\text { CAGGAATCTTCCCAAACGAA } \\
\text { GTTTCTTTGCCAGTGTCTTCACCTTCA }\end{array}$ & 55 & $157-169$ \\
\hline 4 & QGMi005 & JZ532303 & $\begin{array}{l}\text { TGGAGGAATTGAACCGATTG } \\
\text { GTTTCTTCAGTATCGGAGGCGTCAGTC }\end{array}$ & 55 & $303-318$ \\
\hline 5 & QGMi009 & JZ532308 & $\begin{array}{l}\text { GGGTTAGCAAAACTGGTGGA } \\
\text { GTTTCTTCCCCAAGGATATACAGTAACCAG }\end{array}$ & 55 & $156-228$ \\
\hline 6 & QGMi011 & JZ532312 & $\begin{array}{l}\text { CAACTTCCGAAAGCTAGAGGAG } \\
\text { GTTTCTTCGTGGCACTCATTACCACAC }\end{array}$ & 55 & $248-290$ \\
\hline 7 & QGMi013 & JZ532314 & $\begin{array}{l}\text { ATCACGGTTCGGAGAGGTC } \\
\text { GTTTCTTGCAAAAACACGAGGACCAAT }\end{array}$ & 55 & $200-206$ \\
\hline 8 & QGMi015 & JZ532315 & $\begin{array}{l}\text { CAACCACACTTCACGGACAC } \\
\text { GTTTCTTCATGTTTTCGCTGTTGCTGT }\end{array}$ & 55 & $236-247$ \\
\hline 9 & QGMi016 & JZ532316 & $\begin{array}{l}\text { ACCAACGGCAACACCTACA } \\
\text { GTTTCTTCGGCAAATCAAAGGAAAGAA }\end{array}$ & 55 & $257-266$ \\
\hline 10 & QGMi018 & JZ532299 & $\begin{array}{l}\text { GCTCTCTCTGTAACCTTCTTGTTT } \\
\text { GTTTCTTAGTTGTGTCCGTTGTTGCTG }\end{array}$ & 55 & $179-195$ \\
\hline 11 & QGMi021 & JZ532305 & $\begin{array}{l}\text { GCAAGAACCAAGGTGGTGTT } \\
\text { GTTTCTTCCGCTGAAGAAACCTGAGAC }\end{array}$ & 55 & 291 \\
\hline 12 & QGMi025 & JZ532318 & $\begin{array}{l}\text { TAGGGAAGCACAACCACGAT } \\
\text { GTTTCTTGTTCATCCTTGGCTCTCGAC }\end{array}$ & 55 & $300-303$ \\
\hline
\end{tabular}

\section{Data analysis}

The bands produced by the primers were scored using the codes 0 and 1 , where 1 indicates the presence of an allele, and 0 represents the absence of an allele. Only unambiguous bands were scored. Particular bands valuable for the identification of cultivars were tagged with the primer number followed by the approximate size of the amplified fragment in base pairs. Polymorphism was calculated based on the absence and presence of bands. The pairwise genetic distance (Nei 1973) was calculated using POPGENE version 1.32 (hhtp://www. ulaberta.ca/fyeh). The genetic relatedness among cultivars was determined by calculating the genetic distances and identities for all cultivars as per Nei's coefficient. Cluster analysis was performed using the unweighted pair group method with arithmetic averages (UPGMA). The UPGMA dendrogram was constructed based on Nei's pairwise genetic distance using MEGA 6 software. The polymorphic information content (PIC) for each of the SSR markers was calculated using the formula: $\mathrm{PICi}=1-\sum_{\mathrm{j}=1}^{\mathrm{n}}(\mathrm{Pij})^{2}$, where $\mathrm{n}$ is the number of marker alleles for marker I, and Pij is the frequency of the jth allele of marker i (Anderson et al., 1993).

\section{RESULTS}

SSR DNA profiling was used to study the genetic relationships among 15 mango cultivars. PCR amplification resulted in the production of 181 fragments with 12 SSR primers. Of the 12 primers used, 10 were polymorphic $(83 \%)$ producing potentially scoreable banding patterns. The result obtained using one primer is presented in Figure 1. The mean number of effective alleles $\left(N_{\mathrm{E}}\right)$, Nei's genetic diversity $\left(H_{\mathrm{E}}\right)$, Shannon's information index (I), and PIC 
were $1.833,1.436,0.262$, and 0.398 , respectively. Shannon's index is a diversity parameter based upon allele richness (Ward and Jasieniuk, 2009) and is associated with the number of alleles and allele frequency (Zhao, et al. 2006). In the present study, the intra-cultivar value of Shannon's index was low, indicating reduced genetic diversity.

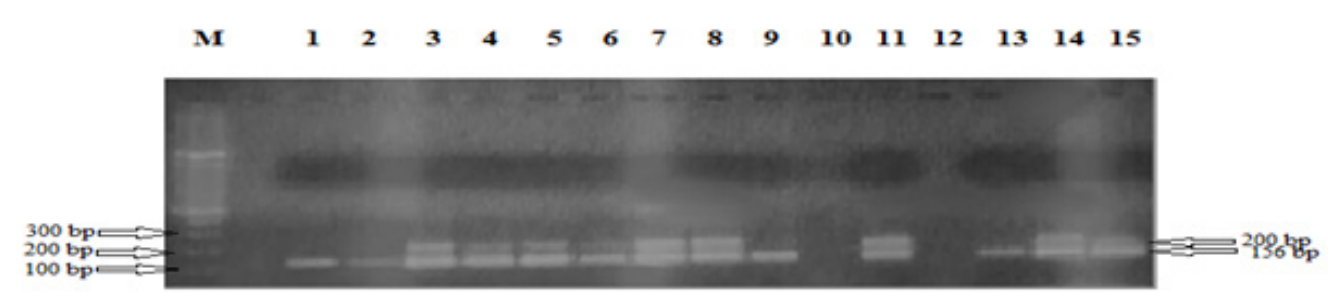

Figure 1. SSR (Simple sequence repeat) profile of mango cultivars produced by primer QMGi 009. This primer is polymorphic and shows genetic variability among 15 mango cultivars. Lane $M=1 \mathrm{~kb}$ plus ladder; lane $1=$ Fajri; lane 2 = Desi; lane $3=$ Kala Chaunsa; lane $4=$ Burma Surkha; lane $5=$ Lahotia; lane $6=$ Sufaid Chaunsa; lane $7=$ Late Ratol No. 12; lane $8=$ Samar Bahisht Chaunsa; lane $9=$ Taimuria; lane $10=$ Neelam; lane 11 = Zafran; lane 12 =Anwar Ratol; lane $13=$ Langra; lane $14=$ Sindhri; lane $15=$ Dusehri.

The PIC value predicts the potential utility of DNA markers for germplasm assessment, molecular breeding, and gene mapping. Markers that exhibit higher PIC values have a greater potential of disclosing allelic variation (Spandana et al., 2012). In the present study, the highest value of PIC was obtained using the QMGi 009 marker, at 0.92 (Table 3). The low level of polymorphism detected in the present study may be due to the low number of SSR markers used, low level of genetic variablity among the mango cultivars, or insufficient coverage of the genome.

Table 3. Genetic diversity parameters of 15 mango genotypes with 12 SSR markers.

\begin{tabular}{l|c|c|c|c}
\hline Marker & $N_{\mathrm{E}}$ & $H_{\mathrm{E}}$ & $\mathrm{I}$ & PIC \\
\hline GMGi001 & 1.567 & 0.311 & 0.468 & 0.45 \\
\hline QMGi002 & 1.462 & 0.240 & 0.337 & 0.32 \\
\hline GMGi003 & 1.000 & 0.000 & 0.000 & 0.00 \\
\hline QMGi005 & 1.000 & 0.000 & 0.000 & 0.00 \\
\hline QMGi009 & 1.642 & 0.580 & 0.447 & 0.67 \\
\hline QMGi011 & 1.386 & 0.391 & 0.245 & 0.56 \\
\hline QMGi013 & 1.142 & 0.276 & 0.500 & 0.36 \\
\hline QMGi015 & 1.471 & 0.124 & 0.691 & 0.36 \\
\hline QMGi016 & 1.991 & 0.320 & 0.373 & 0.67 \\
\hline QMGi021 & 1.306 & 0.498 & 0.637 & 0.55 \\
\hline QMGi025 & 1.800 & 0.222 & 0.500 & 0.36 \\
\hline Mean & 1.471 & 0.444 & 0.262 & 0.398 \\
\hline
\end{tabular}

$N_{\mathrm{E}}=$ no of effective alleles; $H_{\mathrm{E}}=$ Nei's genetic diversity; I = Shannon's information index; PIC = polymorphism information content.

\section{Dendrogram and cluster analysis}

The dendrogram created by UPGMA (Figure 2) was divided into two main clusters: 1 and 2. The horizontal axis of the dendrogram represents the dissimilarity or distance between clusters, whereas the vertical axis of the dendrogram represents clusters. Molecular analysis revealed a high level of genetic similarity among mango cultivars. However, different levels of genetic diversity were also detected. A moderate level of genetic diversity was obtained. Our 
dendrogram revealed similarity coefficients ranging from 75 to $100 \%$. Cluster 1 is the largest cluster and is further divided into two sub-clusters, $1 \mathrm{~A}$ and $1 \mathrm{~B}$, at a genetic distance of 0.18 $(18 \%)$, with a similarity of $82 \%$. Each sub-cluster of cluster 1 is further divided into multiple small clusters. Members of the same cluster are more genetically similar compared with members of other cluster. Sub-cluster 1A contained eight cultivars, namely Kala Chaunsa, Lahotia, Burma Surkha, Sindhri, Sufaid Chaunsa, Samar Bahisht Chaunsa, Dusehri, and Zafran. The two cultivars of sub-cluster 1A (Kala Chaunsa and Lahotia) were 100\% similar with no evidence of genetic diversity. Sub-cluster 1B included six mango cultivars: Anwar Ratol, Langra, Desi, Fajri, Taimuria, and Neelam Late Retol No. 12 was placed in a distinct cluster named cluster 2 . The intraspecific distance among the culivars of cluster $1 \mathrm{~A}$ was 0.13 . Thus, the cultivars of $1 \mathrm{~A}$ share $87 \%$ genetic similarity. Conversely, the genetic distance between the cultivars of subcluster $2 \mathrm{~A}$ is 0.16 ( $84 \%$ similar).

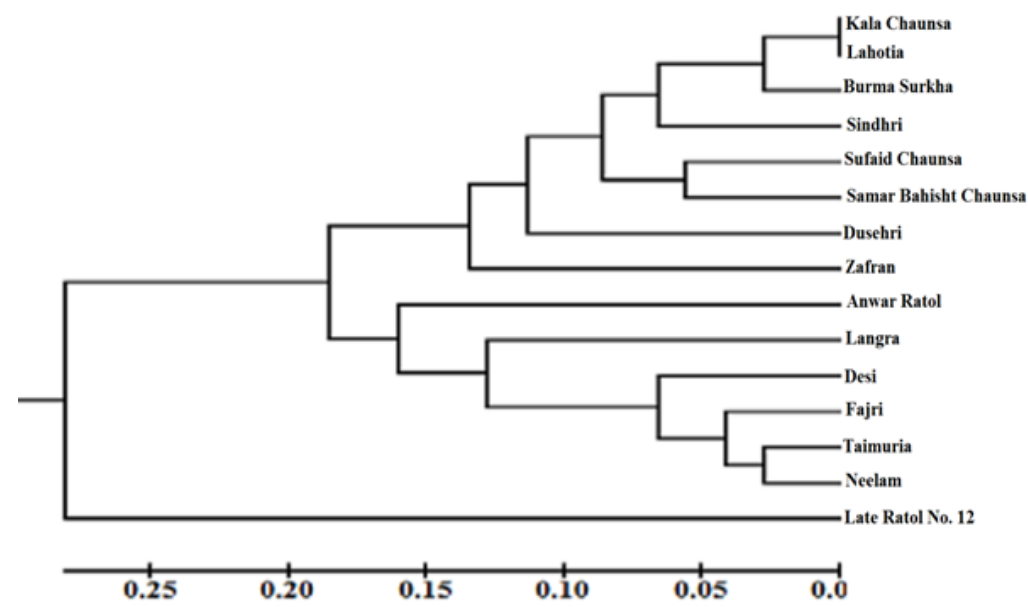

Figure 2. UPGMA (Unweighted Pair Group Method with Arithmetic Mean) dendrogram showing the genetic relationships among 15 mango genotypes.

\section{DISCUSSION}

Determination of genetic diversity among plant species provides important information for varietal development and crop conservation (Romero et al., 2009). Microsatellites have become the markers of choice for use in the genetic fingerprinting of many plant species (Gupta and Varshney, 2000) because of their codominant, highly polymorphic, and reproducible nature. The multi-allelic nature of these markers facilitates the detection of comparative allelic-variability across a large range of germplasm (Joshi et al., 1999).

In the present study, we used 12 SSR markers to reveal genetic diversity among 15 mango cultivars. All the microsatellites amplified resulted in the production of 181 clearly distinguishable bands. Of the 12 markers used, 10 were polymorphic, with QMGi 009 being the most polymorphic, possessing a PIC value of 0.92 . These results confirm the effectiveness of microsatellites when used in studies on genetic diversity. The use of SSR markers is highly recommended to determine genetic differences or similarities among mango cultivars.

Genetics and Molecular Research 16 (2): gmr16029560 
Sixteen microsatellite markers were used by (Viruel et al., 2005), to estimate the geographic distribution of 28 mango genotypes. They revealed $25-100 \%$ genetic similarity, which represents a satisfactory level of genetic diversity. Shamili et al. (2012) found 35-100\% genetic similarity among 41 mango cultivars using 16 SSR markers. Similarly, (Kumar et al., 2013) used 20 SSR markers to study genetic relationships among 10 mango cultivars and reported similarity coefficients of $59-100 \%$, revealing valuable levels of genetic diversity. In the present study, $75-$ $100 \%$ genetic similarity was identified among 15 mango genotypes using 12 SSR markers. This low level of genetic diversity depicts the frequent use of only few parents and inbreeding among selected cultivars. (Schnell et al., 2005) detected heterozygosity values within the range 0.2410.712 when using SSR markers to analyze mango cultivars from Florida; they observed a close genetic relatedness among the germplasm, similar to that in the present study, being subjected to clonal propagation and constant selection, which may result in decreased genetic diversity.

The low level of genetic diversity observed in the present study indicates that mango has a narrow genetic base in Pakistan. We can also conclude that despite extensive breeding practices, the cultivars under current cultivation are close relatives of each other. This is likely due to the use of a few varieties for hybridization or breeding strategies. Hence, it is important to expand the genetic base of cultivated mango to enhance the yield and decrease the vulnerability of this species to various diseases and pests, by incorporating traits found across ecologically adapted genotypes.

\section{CONCLUSION}

The microsatellites used in the present study are important for disclosing genetic diversity among mango cultivars. An understanding of the relationship and diversity among cultivars can facilitate breeders when selecting parent plants with desired genes, such that these genes may be transferred to progeny for the development of novel cultivars.

There is a need to develop a large number of highly polymorphic SSR markers for high quality analyses of mango crops in order to perform comparative mapping or identification of quantitative trait loci. Marker identification is strongly linked to target genes and assessment of their introgression pattern is crucial in order to broaden the genetic base of mango cultivars. Genetic analysis of mango is hindered by the absence of sufficient informative markers, and there is a need to identify high-quality markers.

\section{Conflicts of interest}

The authors declare no conflict of interest.

\section{ACKNOWLEDGMENTS}

The authors are thankful to the staff of the Mango Research Station, Shujabad and Mango Research Centre, Multan, for providing germplasm for this study.

\section{REFERENCES}

Anderson JA, Churchill GA, Autrique JE, Tanksley SD, et al. (1993). Optimizing parental selection for genetic linkage maps. Genome 36: 181-186. http://dx.doi.org/10.1139/g93-024

Genetics and Molecular Research 16 (2): gmr16029560 
Dillon NL, Innes DJ, Bally IS, Wright CL, et al. (2014). expressed sequence tag-simple sequence repeat (EST-SSR) marker resources for diversity analysis of mango (Mangifera indica L.). Diversity (Basel) 6: 72-87. http://dx.doi. org $/ 10.3390 / \mathrm{d} 6010072$

Dos Santos Ribeiro IC, Lima Neto FP and Santos CA (2012). Allelic database and accession divergence of a Brazilian mango collection based on microsatellite markers. Genet. Mol. Res. 11: 4564-4574. http://dx.doi.org/10.4238/2012. October.9.4

Doyle JJ and Doyle JL (1990). Isolation of plant DNA from fresh tissue. Focus 12: 13-15.

Food and Agriculture Organization Report (2013). Production year book. http://www.fao.org/docrep/018/i3107e/i3107e00.htm

Gupta PK and Varshney R (2000). The development and use of microsatellite markers for genetic analysis and plant breeding with emphasis on bread wheat. Euphytica 113: 163-185. http://dx.doi.org/10.1023/A:1003910819967

Honsho C, Nishiyama K, Eiadthong W and Yonemori K (2005). Isolation and characterization of new microsatellite markers in mango (Mangifera indica). Mol. Ecol. Notes 5: 152-154. http://dx.doi.org/10.1111/j.1471-8286.2004.00866.x

Joshi SP, Ranjekar PK and Gupta VS (1999). Molecular markers in plant genome analysis. Curr. Sci. 77: 230-240.

Kobayashi A, Ebana K, Fukuoka S and Nagamine T (2006). Microsatellite markers revealed the genetic diversity of an old Japanese rice landrace 'Echizen'. Genet. Resour. Crop Evol. 53: 499-506. http://dx.doi.org/10.1007/s10722-004-2029-z

Kumar M, Ponnuswami V, Nagarajan P, Jeyakumar P, et al. (2013). Molecular characterization of ten mango cultivars using simple sequences repeat (SSR) markers. Afr. J. Biotechnol. 12: 6568-6573. http://dx.doi.org/10.5897/AJB2013.12797

Nei M (1973). The theory and estimation of genetic distance. In: Genetic structure of populations (Morton NE, ed.). University Press of Hawaii, Honolulu, 45-54.

Parida SK, Kalia SK, Kaul S, Dalal V, et al. (2009). Informative genomic microsatellite markers for efficient genotyping applications in sugarcane. Theor. Appl. Genet. 118: 327-338. http://dx.doi.org/10.1007/s00122-008-0902-4

Rashad M, Balal M, Mumtaz K, Adnan SK, and Waqas M. (2012). Mango cultivation in Pakistan. Institute of Horticulture Sciences, Agrihunt.

Ravishankar KV, Bommisetty P, Bajpai A, Srivastava N, et al. (2015). Genetic diversity and population structure analysis of mango (Mangifera indica) cultivars assessed by microsatellite markers. Trees (Berl.) 29: 775-783. http://dx.doi. org $/ 10.1007 / \mathrm{s} 00468-015-1155-\mathrm{x}$

Romero G, Adeva C and Battad Z (2009). Genetic fingerprinting: advancing the frontiers of crop biology research. Philipp. Sci. Lett. 2: 8-13.

Schnell R, Olano C, Quintanilla W and Meerow A (2005). Isolation and characterization of 15 microsatellite loci from mango (Mangifera indica L.) and cross species amplification in closely related taxa. Mol. Ecol. Notes 5: 625-627. http://dx.doi.org/10.1111/j.1471-8286.2005.01018.x

Shamili M, Fatahi R and Hormaza J (2012). Characterization and evaluation of genetic diversity of Iranian mango (Mangifera indica L., Anacardiaceae) genotypes using microsatellites. Sci. Hortic. (Amsterdam) 148: 230-234. http:// dx.doi.org/10.1016/j.scienta.2012.09.031

Spandana B, Reddy VP, Prasanna GJ, Anuradha G, et al. (2012). Development and characterization of microsatellite markers (SSR) in Sesamum (Sesamum indicum L.) species. Appl. Biochem. Biotechnol. 168: 1594-1607. http:// dx.doi.org/10.1007/s12010-012-9881-7

Varshney RK, Graner A and Sorrells ME (2005). Genic microsatellite markers in plants: features and applications. Trends Biotechnol. 23: 48-55. http://dx.doi.org/10.1016/j.tibtech.2004.11.005

Viruel M, Escribano P, Barbieri M, Ferri M, et al. (2005). Fingerprinting, embryo type and geographic differentiation in mango (Mangifera indica L., Anacardiaceae) with microsatellites. Mol. Breed. 15: 383-393. http://dx.doi. org/10.1007/s11032-004-7982-x

Ward SM and Jasieniuk M (2009). Review: sampling weedy and invasive plant populations for genetic diversity analysis. Weed Sci. 57: 593-602. http://dx.doi.org/10.1614/WS-09-082.1

Zhao R, Cheng Z, Lu W and Lu B (2006). Estimating genetic diversity and sampling strategy for a wild soybean (Glycine soja) population based on different molecular markers. Chin. Sci. Bull. 51: 1219-1227. http://dx.doi.org/10.1007/ $\underline{\text { s11434-006-1219-9 }}$

Genetics and Molecular Research 16 (2): gmr16029560 